\title{
Comparative Electrophoretic Polymorphism of Esterases and Other Enzymes in Escherichia coli
}

\author{
By Ph. GOUllet* and B. PICARD \\ Laboratoire de Microbiologie, Faculté de Médecine Xavier-Bichat (Université Paris VII), \\ 16 rue Henri Huchard, 75018 Paris, France
}

(Received 4 July 1988; accepted 22 September 1988)

\begin{abstract}
The electrophoretic polymorphism of esterases was compared with that of other enzymes in Escherichia coli populations by investigating allozyme distribution of four esterases (A, B, C and I) within both the subspecific groups I, II and III and the new groups A, B1, B2, C, D and E, which have been distinguished by electrophoretic analysis of 11 and 35 enzymes respectively in the 72 reference strains of the ECOR collection. Electrophoretic distribution of esterases was distinct for each of the three subspecific groups as indicated by distributions of allozymes and electrophoretic types (distinctive combination of allozyme for the four esterases). Esterase polymorphisms of the three subspecific groups appeared to have similar features to those of three previously studied natural populations of strains obtained from human and animal gastrointestinal tracts and extra-intestinal infections in humans. Multiple correspondence analyses using data obtained from the four esterases and the 11 other enzymes also distinguished the groups A, B1, B2, C, D and E. All strains of group B2 showed the $\mathbf{B}_{2}$ electrophoretic pattern of esterase $B$, which appeared to be a marker of a distinct cluster of strains frequently implicated in extra-intestinal infections.
\end{abstract}

\section{INTRODUCTION}

Four kinds of electrophoretically variable esterases, designated A, B, C and I, have been characterized in Escherichia coli by their distinct spectra of activity on synthetic substrates and by their sensitivity or resistance to di-isopropyl fluorophosphate (Goullet, 1973, 1980). A survey of the electrophoretic polymorphism of these esterases revealed three associations of allozymes in natural $E$. coli populations obtained from three distinct sources [animal intestinal strains (AIS), human intestinal strains (HIS) and human extra-intestinal infection strains (HES)]. The first association, characterized by slow electrophoretic mobilities $\left(M_{F}\right.$ values) of esterase B (from $M_{F} \simeq 57$ to $M_{F} \simeq 63$ ), was frequently observed in HES. The second, characterized by the fast mobilities of esterases A and B $\left(M_{F} \simeq 81\right.$ and $M_{F} \simeq 72$ respectively), was frequently found in AIS. The third, characterized by prominence of the most common mobilities of esterases $\mathrm{A}$ and B $\left(M_{F} \simeq 75\right.$ and $M_{F} \simeq 70$ respectively), was found in all three populations (Goullet \& Picard, $1986 a)$.

Ochman \& Selander (1984) have assembled a set of 72 E. coli reference (ECOR) strains isolated from a variety of hosts and geographical locations. These strains are representative of the genotypic diversity in the species and are available to investigators concerned with the analysis of variation and genetic structure in natural populations. These strains, which were initially characterized by electrophoresis of 11 enzymes other than esterases and distributed according to the subspecific groups I, II, III (Ochman et al., 1983; Whittam et al., 1983) were

\footnotetext{
Abbreviations: AIS, animal intestinal strains; $E_{t}$, electrophoretic type; GDC, genetic diversity coefficient; HES, human extra-intestinal infection strains; HIS, human intestinal strains; IEF, isoelectrofocusing; MCA, multiple correspondence analysis; $M_{F}$, electrophoretic mobility; MRHA, mannose resistant haemagglutinin.
} 
recently characterized by electrophoresis of 35 enzymes and redistributed into six new groups designated A, B1, B2, C, D and E (Selander et al., 1987).

In the present work, we analysed electrophoretic variations of esterases A, B, C and I in the ECOR collection to investigate their allozyme distribution within both the three subspecific groups and the six new groups of strains. Esterase polymorphism of the ECOR strains was also compared with that of the three previously surveyed populations (AIS, HIS and HES).

\section{METHODS}

Bacterial strains. The 72 strains of the ECOR collection were provided by R. K. Selander. Details of the sources of the strains were indicated by Ochman \& Selander (1984). All isolates were cultured in Fernbach flasks containing $500 \mathrm{ml} \mathrm{L}$ broth without glucose and, concomitantly for some strains, in minimal salt medium M-63 (Pardee et al., 1959) supplemented with $2 \mathrm{~g}$ glycerol $1^{-1}$. The flasks were shaken vigorously for $18 \mathrm{~h}$ at $37^{\circ} \mathrm{C}$ in a reciprocating water-bath shaker set at about 70 oscillations $\mathrm{min}^{-1}$.

Electrophoretic analysis. The preparation of extracts, protein estimation, horizontal slab polyacrylamide agarose gel electrophoresis (7\%, w/v, acrylamide; Tris/glycine buffer, $\mathrm{pH} \mathrm{8.6),} \mathrm{estimation} \mathrm{of} M_{F}$, isoelectrofocusing (IEF) and esterase staining have been described previously (Goullet \& Picard, 1985). Each $M_{F}$ variant was designated as an allozyme (electromorph). When an esterase was not detected in a strain, it was recorded as 'null allozyme' (and scored 0 ). Each distinctive combination of allozymes for the four varieties of esterases was designated as an electrophoretic type $\left(E_{\mathrm{t}}\right)$.

$\alpha$-Haemolysin and mannose resistant haemagglutinin (MRHA) assays. These were done as previously described (Goullet \& Picard, 1986b).

Statistical analyses. Multiple correspondence analyses (MCA) (Greenacre, 1984; Lebart et al., 1984; Tenenhaus \& Young, 1985) were done using the SPAD.N program from Centre International de Statistique et d'Informatique Appliquées, Sèvres, France.

Genetic diversity. Genetic diversity coefficient (GDC) values were calculated according to Nei (1978). $\mathrm{GDC}(H)=1-\sum x_{\mathrm{i}}^{2}[n /(n-1)]$ where $x_{\mathrm{i}}$ is the frequency of each allozyme and $n$ is the number of strains in the samples.

\section{RESULTS}

\section{Electrophoretic types and $p I$ of esterase $B$}

Among the 72 strains, 49 electrophoretic types (distinct combination of allozymes for esterases B, A, C and I: $\left.E_{\mathrm{tBACl}}\right)$ were characterized (Table 1). They were 16,20 and $14 E_{\mathrm{tBACI}}$ for subspecific groups I, II and III (Ochman et al., 1983) respectively. Strain 38 of subspecific group II and strain 70 of subspecific group III showed the same $E_{\mathrm{tBACI}}$ but were distinguished by the pI value of esterase B. In five other cases, strains having an identical $E_{\mathrm{tBACI}}$ could be distinguished by the pI of esterase B (strains 30,39 and 40; strains 58 and 72 ; strains 56 and 57; strains 51, 52 and 54; and strains 63, 64 and 67). Differentiation between (i) strains 32 and 33, (ii) strains 38, 40 and 41, (iii) strains 51 and 54-56 and (iv) strains 53 and 60, which was not possible

\section{Table 1. Esterase electrophoretic data on the 72 ECOR strains}

\begin{tabular}{|c|c|c|c|c|c|c|c|}
\hline \multirow[b]{2}{*}{$\begin{array}{c}\text { ECOR } \\
\text { strain no. }\end{array}$} & \multirow{2}{*}{$\begin{array}{l}\text { Subspecific group } \\
\text { characterized by } \\
\text { electrophoresis } \\
\text { of } 11 \text { enzymes } \\
\text { (Ochman \& } \\
\text { Selander, 1984) }\end{array}$} & \multirow{2}{*}{$\begin{array}{l}\text { New group } \\
\text { characterized by } \\
\text { electrophoresis } \\
\text { of } 35 \text { enzymes } \\
\text { (Selander } \\
\text { et al., 1987) }\end{array}$} & \multicolumn{4}{|c|}{$\begin{array}{c}\text { Esterase } \\
\text { electrophoretic type } \\
\left(E_{\mathrm{tBACI}}\right)\end{array}$} & \multirow{2}{*}{$\overbrace{\begin{array}{c}\text { B } \\
(\mathrm{pI})\end{array}}^{\mathrm{IEF}}$} \\
\hline & & & $\begin{array}{c}\mathrm{B}^{*} \\
\left(M_{F}\right)\end{array}$ & $\begin{array}{c}\text { A } \\
\left(M_{F}\right)\end{array}$ & $\begin{array}{c}\mathrm{C} \\
\left(M_{F}\right)\end{array}$ & $\begin{array}{c}I \\
\left(M_{F}\right)\end{array}$ & \\
\hline 1 & I & A & 70 & 75 & 60 & 0 & $4 \cdot 6$ \\
\hline 2 & I & A & 70 & 75 & 44 & 70 & $4 \cdot 6$ \\
\hline 3 & I & $\mathbf{A}$ & 70 & 75 & 60 & 70 & $4 \cdot 6$ \\
\hline 4 & I & $\mathbf{A}$ & 68 & 75 & 0 & 60 & 4.75 \\
\hline 5 & I & A & 70 & 75 & 60 & 70 & $4 \cdot 6$ \\
\hline 6 & I & A & 68 & 75 & 55 & 68 & 4.75 \\
\hline 7 & I & A & 70 & 75 & 44 & 72 & $4 \cdot 6$ \\
\hline 8 & I & A & 70 & 75 & 60 & 70 & $4 \cdot 6$ \\
\hline 9 & I & A & 70 & 75 & 60 & 70 & $4 \cdot 6$ \\
\hline
\end{tabular}


Table 1. (continued)

\begin{tabular}{|c|c|c|c|c|c|c|c|}
\hline \multirow[b]{2}{*}{$\begin{array}{c}\text { ECOR } \\
\text { strain no. }\end{array}$} & \multirow{2}{*}{$\begin{array}{l}\text { Subspecific group } \\
\text { characterized by } \\
\text { electrophoresis } \\
\text { of } 11 \text { enzymes } \\
\text { (Ochman \& } \\
\text { Selander, 1984) }\end{array}$} & \multirow{2}{*}{$\begin{array}{l}\text { New group } \\
\text { characterized by } \\
\text { electrophoresis } \\
\text { of } 35 \text { enzymes } \\
\text { (Selander } \\
\text { et al., 1987) }\end{array}$} & \multicolumn{4}{|c|}{$\begin{array}{c}\text { Esterase } \\
\text { electrophoretic type } \\
\left(E_{\mathrm{tBACl}}\right)\end{array}$} & \multirow{2}{*}{$\overbrace{\begin{array}{c}\text { B } \\
(\mathrm{pI})\end{array}}^{\mathrm{IEF}}$} \\
\hline & & & $\begin{array}{c}\mathrm{B}^{*} \\
\left(M_{F}\right)\end{array}$ & $\stackrel{\mathrm{A}}{\left(M_{F}\right)}$ & $\begin{array}{c}\mathrm{C} \\
\left(M_{F}\right)\end{array}$ & $\stackrel{\text { I }}{\left(M_{F}\right)}$ & \\
\hline 10 & I & A & 70 & 75 & 60 & 70 & 4.6 \\
\hline 11 & I & $\mathbf{A}$ & 70 & 75 & 60 & 70 & $4 \cdot 6$ \\
\hline 12 & I & A & 70 & 75 & 60 & 70 & $4 \cdot 6$ \\
\hline 13 & I & A & 70 & 75 & 63 & 0 & $4 \cdot 6$ \\
\hline 14 & I & A & 70 & 75 & 44 & 70 & 4.6 \\
\hline 15 & I & A & 68 & 75 & 44 & 0 & 4.75 \\
\hline 16 & I & A & 68 & 75 & 60 & 68 & 4.75 \\
\hline 17 & I & A & 68 & 75 & 60 & 0 & 4.75 \\
\hline 18 & I & A & 68 & 75 & 48 & 70 & 4.75 \\
\hline 19 & I & A & 68 & 75 & 40 & 68 & 4.75 \\
\hline 20 & I & A & 68 & 75 & 40 & 73 & 4.75 \\
\hline 21 & I & A & 68 & 75 & 40 & 73 & 4.75 \\
\hline 22 & I & A & 68 & 75 & 57 & 62 & $4 \cdot 75$ \\
\hline 23 & I & A & 70 & 75 & 59 & 0 & $4 \cdot 6$ \\
\hline 24 & I & A & 68 & 75 & 59 & 65 & 4.75 \\
\hline 25 & I & A & 70 & 75 & 60 & 70 & $4 \cdot 6$ \\
\hline 26 & II & C & 70 & 78 & 57 & 75 & 4.6 \\
\hline 27 & II & C & 70 & 78 & 57 & 75 & 4.6 \\
\hline 28 & II & B1 & 72 & 78 & 57 & 72 & $4 \cdot 75$ \\
\hline 29 & II & B1 & 70 & 81 & 57 & 70 & 4.75 \\
\hline 30 & II & Bl & 70 & 75 & 57 & 70 & 4.75 \\
\hline 31 & II & B1 & 73 & 78 & 57 & 72 & 4.5 \\
\hline 32 & II & B1 & 72 & 75 & 57 & 72 & 4.75 \\
\hline 33 & II & B1 & 72 & 75 & 59 & 72 & $4 \cdot 75$ \\
\hline 34 & II & B1 & 72 & 81 & 57 & 70 & $4 \cdot 75$ \\
\hline 35 & II & D & 70 & 75 & 62 & 68 & $4 \cdot 6$ \\
\hline 36 & II & D & 70 & 75 & 62 & 68 & 4.6 \\
\hline 37 & II & $\overline{\mathbf{E}}$ & 70 & 75 & 0 & 61 & $4 \cdot 6$ \\
\hline 38 & II & D & 72 & 75 & 57 & 70 & 4.75 \\
\hline 39 & II & D & 70 & 75 & 57 & 70 & $4 \cdot 6$ \\
\hline 40 & II & D & 70 & 75 & 57 & 70 & 4.6 \\
\hline 41 & II & D & 73 & 75 & 57 & 70 & 4.5 \\
\hline 42 & II & B1 & 70 & 0 & 60 & 72 & 4.6 \\
\hline 43 & II & B1 & 70 & 75 & 0 & 70 & 4.5 \\
\hline 44 & II & D & 70 & 75 & 55 & 65 & $4 \cdot 6$ \\
\hline 45 & II & B1 & 72 & 78 & 55 & 72 & 4.75 \\
\hline 46 & II & D & 70 & 0 & 0 & 65 & $4 \cdot 6$ \\
\hline 47 & II & D & 72 & 75 & 48 & 0 & 4.9 \\
\hline 48 & II & C & 72 & 75 & 55 & 74 & 4.5 \\
\hline 49 & II & D & 72 & 75 & 0 & 65 & 4.5 \\
\hline 50 & II & D & 72 & 75 & 0 & 65 & 4.5 \\
\hline 51 & III & B2 & 57 & 78 & 60 & 72 & 5 \\
\hline 52 & III & B2 & 57 & 78 & 60 & 72 & 5 \\
\hline 53 & III & B2 & 60 & 75 & 55 & 70 & $4 \cdot 85$ \\
\hline 54 & III & B2 & 57 & 78 & 60 & 72 & 4.9 \\
\hline 55 & III & B2 & 57 & 75 & 60 & 75 & 4.9 \\
\hline 56 & III & B2 & 57 & 78 & 61 & 75 & 4.9 \\
\hline 57 & III & B2 & 57 & 78 & 61 & 75 & 5 \\
\hline 58 & III & C & 70 & 78 & 57 & 70 & 4.75 \\
\hline 59 & III & B2 & 62 & 75 & 59 & 61 & 4.85 \\
\hline 60 & III & B2 & 60 & 75 & 61 & 61 & $4 \cdot 85$ \\
\hline 61 & III & B2 & 62 & 78 & 60 & 70 & 4.85 \\
\hline 62 & III & B2 & 62 & 78 & 60 & 70 & 4.85 \\
\hline 63 & III & B2 & 57 & 78 & 60 & 70 & 4.9 \\
\hline 64 & III & B2 & 57 & 78 & 60 & 70 & 5 \\
\hline 65 & III & B2 & 57 & 75 & 60 & 72 & 5 \\
\hline 66 & III & B1 & 57 & 78 & 60 & 0 & 5 \\
\hline
\end{tabular}




$\begin{array}{cc}\text { Subspecific group } \\ \text { characterized by } \\ \text { electrophoresis } \\ \text { of 11 enzymes } \\ \text { (Ochman \& } \\ \text { ECOR } & \text { Selander, 1984) } \\ \text { strain no. } & \text { III } \\ 67 & \text { III } \\ 68 & \text { III } \\ 69 & \text { III } \\ 70 & \text { III } \\ 71 & \text { III }\end{array}$

Table 1. (Continued)

\begin{tabular}{|c|c|c|c|c|c|}
\hline \multirow{2}{*}{$\begin{array}{l}\text { New group } \\
\text { characterized by } \\
\text { electrophoresis } \\
\text { of } 35 \text { enzymes } \\
\text { (Selander } \\
\text { et al., 1987) }\end{array}$} & \multicolumn{4}{|c|}{$\begin{array}{c}\text { Esterase } \\
\text { electrophoretic type } \\
\left(E_{\text {tBACI }}\right)\end{array}$} & \multirow{2}{*}{$\overbrace{\begin{array}{c}\text { B } \\
(\mathrm{pI})\end{array}}^{\text {IEF }}$} \\
\hline & $\begin{array}{c}\mathrm{B}^{*} \\
\left(M_{F}\right)\end{array}$ & $\begin{array}{c}\mathrm{A} \\
\left(M_{F}\right)\end{array}$ & $\underset{\left(M_{F}\right)}{C}$ & $\begin{array}{c}\mathrm{I} \\
\left(M_{F}\right)\end{array}$ & \\
\hline B1 & 57 & 78 & 60 & 70 & 5 \\
\hline B1 & 72 & 0 & 57 & 70 & 4.75 \\
\hline $\mathrm{C}$ & 70 & 78 & 57 & 72 & $4 \cdot 6$ \\
\hline C & 72 & 75 & 57 & 70 & $4 \cdot 8$ \\
\hline B1 & 72 & 0 & 57 & 70 & 4.75 \\
\hline C & 70 & 78 & 57 & 70 & $4 \cdot 6$ \\
\hline
\end{tabular}

* Electrophoretic mobilities corresponding to pattern $B_{2}$ are shown in bold type.

Table 2. Electrophoretic distribution of esterases $A, B, C$ and $I$ in groups $I, I I$ and III

Values are the number of strains with each allozyme; particularly significant values are in bold type. GI, II, III, groups I, II and III; Na, null allozyme.

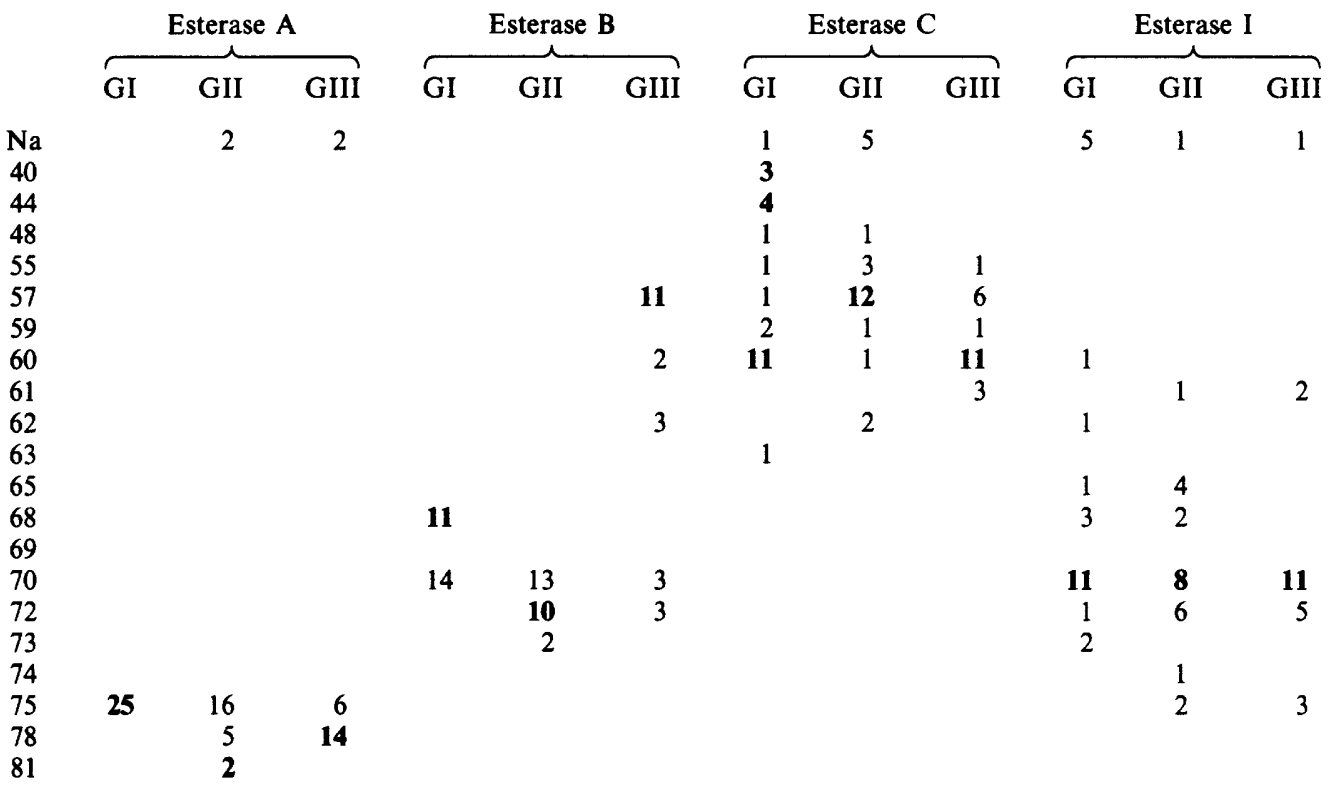

using electrophoresis of 35 enzymes (Selander et al., 1987) was obtained by electrophoresis of the four esterases. For strain 54 this differentiation was only confirmed by a distinct pI value.

Distribution of esterase allozymes in the three subspecific groups (Table 2)

For esterase A, allozyme A-75 was detected in all strains of group I and in the majority of strains of group II; allozyme A-78 was prevalent in strains of group III. For esterase B, allozyme B-68 was observed only in strains of group I; allozyme B-70 was more frequent in groups I and II; allozymes B-72 and B-73 were detected principally in group II strains. Allozymes B-57, B-60 and B-62 were detected only in group III. For esterase C, allozyme C-57 was prevalent in strains of group II and allozyme C-60 in strains of groups I and III; allozymes C-40 and C-44 were observed only in group I strains. For esterase I, allozyme I-70 was prevalent in all three groups. 


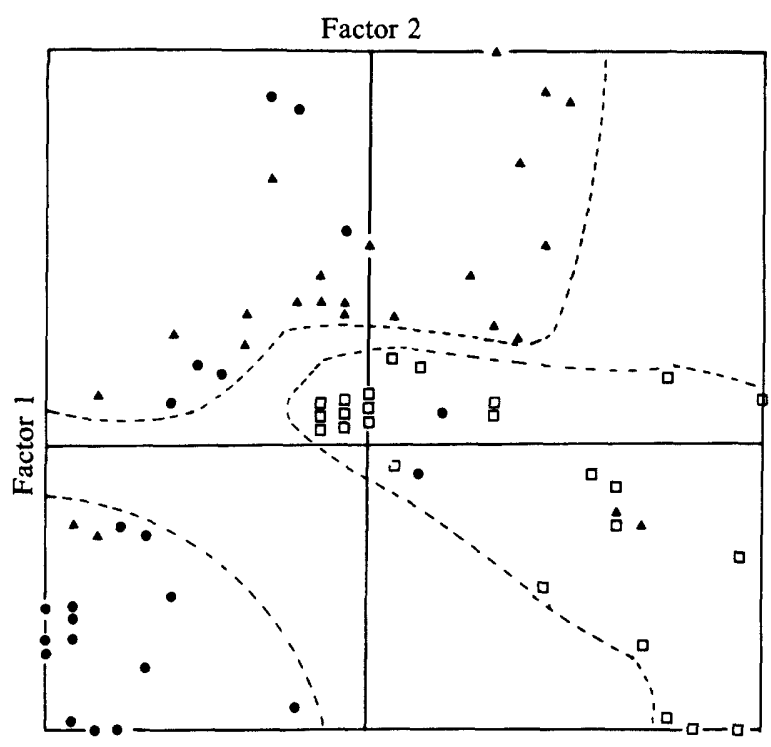

Fig. 1. MCA of the ECOR strains using the four esterases. Plot of score of strains for the first two principal factors: $\square$, group I: $\Delta$, group II: $\boldsymbol{O}$, group III.

\section{Genetic diversity}

The GDCs (Nei, 1978, Selander et al., 1986) determined in the 72 strains were as follows: 0.497 for esterase A; 0.742 for esterase B; 0.804 for esterase C; and 0.771 for esterase I. Mean GDCs of the 72 strains and of each of the three subspecific groups were higher for the esterases (for the 72 strains, 0.703 ; group I, 0.485 ; group II, 0.636 ; and group III, 0.621 ) than for the other enzymes (for the 72 strains, $0 \cdot 465$; group I, 0.239 ; group II, 0.332 ; and group III, $0 \cdot 322$ ) (Ochman \& Selander, 1984).

\section{Multiple correspondence analyses}

MCA using data for the four esterases. The first two factors accounted for $16.8 \%$ of the total variance. Projections of different allozymes on the first two axes revealed that the first factor separated allozymes B-57, B-62, A-78, C-61, C-60 and I-75 from allozymes B-68, C-40 and I-73, whereas allozymes B-72, A-81, A-0, C-57 and C-55 were distinguished by the second factor. Projections of the 72 ECOR strains according to the four esterases correlated well with their allocation to the three subspecific groups defined by Ochman \& Selander (1984) (Fig. 1): all strains of group I were clustered; among the strains of group II, only two strains ( 35 and 36) were recovered with the strains of group I and two strains ( 26 and 27 ) with those of group III; for the strains of group III, two strains (53 and 59) were recovered with strains of group I and six (strains 58 and 68 to 72) with those of group II.

MCA using both allozymes of the four esterases and the 11 other enzymes. The first two factors accounted for $14.4 \%$ of the total variance. Projections of different allozymes on the first two axes revealed that the first factor separated allozymes B-57, C-61, I-75, 6PG3, PEZ-2 and A-78 from allozymes G6P-1, 6PG-19, C-40 and B-68; the second factor distinguished between allozymes MDH-5, PGI-9, IDH-3, GOT-2, B-72, A-81 and C-55. Projections of the 72 ECOR strains on the basis of the 15 enzymes distinguished four groups (Fig. 2): groups A and B1 were distinguished along the first axis; groups B2 and D were separated by the second axis, whereas strains of group $\mathrm{C}$ failed to cluster. The dendrogram obtained from this analysis clearly classified the majority of strains to the six new groups defined by Selander et al. (1987) (Fig. 3). 


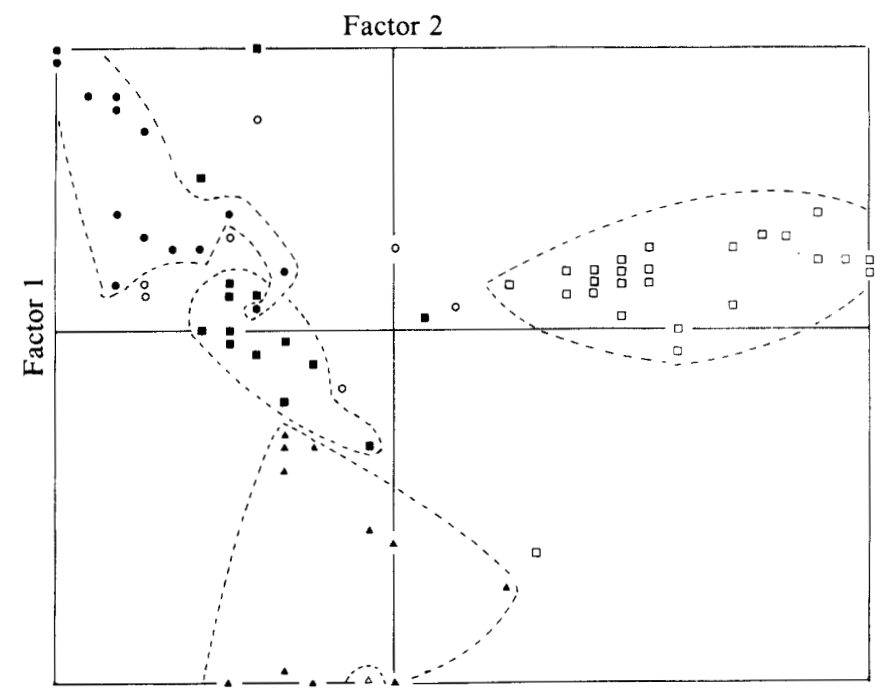

Fig. 2. MCA of the ECOR strains using allozymes of the four esterases and of 11 other enzymes. Plot of score of strains for the first two principal factors: $\square$, group $A ; \square$, group B1;, group B2; 0 , group C; $\Delta$, group $\mathrm{D} ; \Delta$, group $\mathrm{E}$.

\section{Two-dimensional plotting of electrophoretic data for esterase $B$}

A two-dimensional representation of the electrophoretic data (Goullet $\&$ Picard, 1985) was obtained by plotting the isoelectric points against electrophoretic mobility for esterase B detected in the 72 ECOR strains and, for comparison, in the collection of 610 strains constituted by AIS, HIS and HES. Of the 13 variants of esterase B defined by their $\mathrm{pI}$ and $M_{F}$ values in ECOR strains (Table 1), 12 belonged to the 41 variants previously described (Picard et al., 1987) while a new variant (pI 4.9/MF $\simeq 72$ ) was detected in strain 47 . Strains of groups A, B1, C, D and E were characterized by electrophoretic pattern $\mathrm{B}_{1}$ (from $M_{F} \simeq 66$ to $M_{F} \simeq 74$ and from pI 4.5 to pI 4.9) (Goullet \& Picard, 1986b) (with the exception of strains 66 and 67 of group B1). All strains of group B2 were distributed in pattern $\mathrm{B}_{2}$ (from $M_{F} \simeq 57$ to $M_{F} \simeq 66$ and from pI 4.8 to pI 5). The most frequent variant, (pI 4.6/MF $\simeq 70$ ), was detected in the three subspecific groups and in new groups A, B1, C, D and E. Strains of group A were distributed into only two variants, the major variant and variant pI $4 \cdot 75 / M_{F} \simeq 68$, which were previously considered to be related by a single amino acid substitution (an acidic amino acid replaced by a neutral amino acid) (Picard et al., 1987). Strains of groups B1, C and D were considerably more heterogeneous than strains of group A and displayed variants ranging from $M_{F} \simeq 57$ to $M_{F} \simeq 73$ and from pI 4.5 to pI 5. Four strains of group $C$ and six of group D showed the major variant. Only one strain of the two groups had variant pI $4 \cdot 75 / M_{F} \simeq 72$, whereas six of the 13 strains of group B1 had this variant (which we consider to be separated from the major variant by at least two successive mutations: Picard et al., 1987). Of the 16 strains of pattern $\mathbf{B}_{2}$, six produced an $\alpha$-haemolysin and eight a MRHA (four produced both virulence factors). In contrast, of the 56 strains showing pattern $B_{1}$, no strain produced an $\alpha$-haemolysin and only three a MRHA.

\section{DISCUSSION}

As was observed in our previous analysis of AIS, HIS and HES (Goullet \& Picard, 1986a), esterases are highly polymorphic, since the number of electrophoretic types (49) defined in the ECOR collection by electrophoretic analysis of the four esterases is similar to that (48) defined by analysis of the 11 other enzymes (Ochman \& Selander, 1984). In addition, the findings obtained by the combination of conventional electrophoresis and IEF of esterases were complementary for strain differentiation to those obtained by electrophoresis of 35 enzymes, 


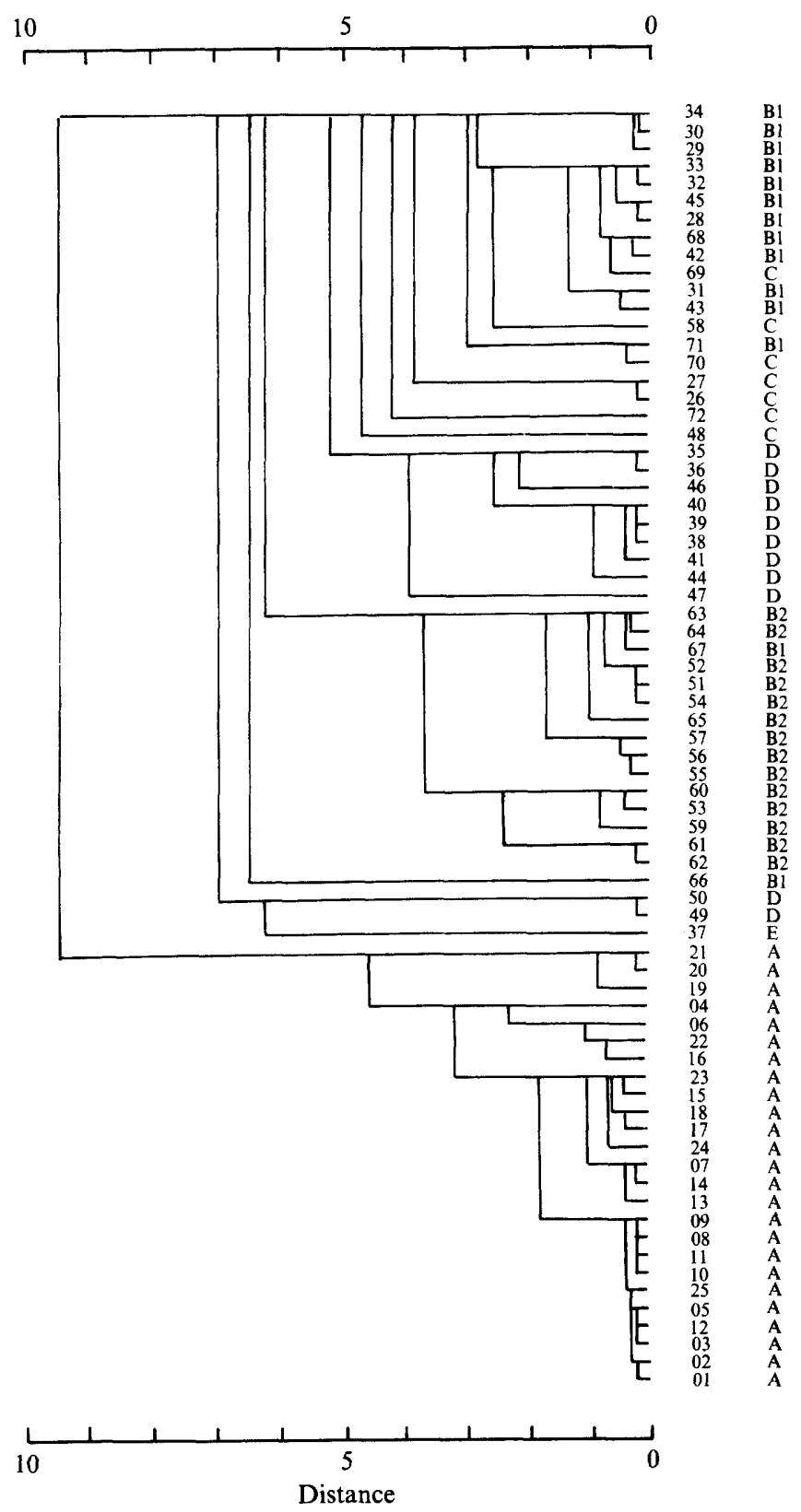

Fig. 3. Dendrogram representation of the data obtained from the whole MCA of the ECOR strains using allozymes of the four esterases and of 11 other enzymes.

with 69 electrophoretic profiles finally being distinguished. Thus, differentiation between $E$. coli strains increased with both the diversity of enzymes examined and the diversity of electrophoretic criteria used.

MCA using both the 72 ECOR strains and the collection of 610 strains for electrophoretic variations of esterases showed that the ECOR strains displayed a wide distribution throughout the plane of the first two factors and consequently that the two collections of strains were analogous in terms of esterase electrophoretic polymorphism. However, only one ECOR strain, which was identified by the negative value of factor 1 , exhibited allozymes B-72 and A-81, 
whereas this association of allozymes was frequently observed in the collection of 610 strains, especially in $8.5 \%$ of the 211 AIS. Although allozymes of the four esterases produced by ECOR strains were detected earlier (with the exception of allozyme C-40), only 19 of the $49 E_{\mathrm{tBACI}}$ revealed in the present study were observed among the $316 E_{\mathrm{tBACI}}$ previously characterized (Goullet \& Picard, 1986a).

Electrophoretic distribution of esterases was distinct for each of the three subspecific groups, as indicated by the distributions of electrophoretic types (Table 1) and allozymes (Table 2). Esterase polymorphism in groups I, II and III appeared to have similar features to that in HIS, AIS and HES. Strains of group I resembled HIS by the prevalence of the most common mobilities of esterase $\mathrm{A}\left(M_{F} \simeq 75\right)$ and of esterase $\mathrm{B}\left(M_{F} \simeq 70\right)$, by the relatively high proportion of allozymes B-68 and C-60 and by the high frequency of the association of allozymes B-70, A-75 and C-60 (displayed by nine ECOR strains and by $12 \%$ of the 142 HIS). Group I was electrophoretically more homogeneous than groups II and III both for the esterases and for the 11 other enzymes (see mean GDC values and Table 1). This homogeneity was substantiated by the occurrence of only two variants of esterase B. These were related to each other by a single amino acid substitution. The most frequent variant ( $\mathrm{pI} 4 \cdot 6 / M_{F} \simeq 70$ ) was also detected in the two other subspecific groups and in the new groups A, B1, C, D and E. Its wide distribution in AIS, HIS and in HES, in Shigella sonnei (Goullet \& Picard, 1987) and in the ECOR strains, which are representative of the genetic diversity in the species as a whole (Ochman \& Selander, 1984), suggests that this major variant remained stable throughout the process of evolutionary differentiation within the $E$. coli genospecies.

Strains of group II resembled AIS by their higher proportion of allozymes B-72 and C-57, their lower proportion of allozyme C-60 and the presence of allozyme A-81. Thus, the ratio between the number of strains having allozyme C-57 and the number of strains having allozyme C-60 (C-57/C-60) was higher for group II (12) than for either group III (0.54) or group I (0.09). An analysis of 35 enzymes resulted in the distribution of 21 strains of group II into groups B1 and D (Selander et al., 1987). This was also found by MCA using a combination of allozymes of esterases and of 11 other enzymes (Figs 2 and 3). Five of the six strains of group $B_{1}$ having the variant pI $4 \cdot 75 / M_{F} \simeq 72$ were of animal origin. This observation was corroborated by data obtained in previous work (Picard et al., 1987) in which this variant was detected in $10.9 \%$ of AIS and but in only $2.8 \%$ of HIS and $0.39 \%$ of HES.

Strains of group III resembled HES by their relatively high proportions of allozymes B-57, A-78 and $E_{\mathrm{tBAC}}$ (seven ECOR strains and $12.5 \%$ of HES contained B-57, A-78 and C-60). Of the 22 strains in this group, 16 showed slow mobilities of esterase B corresponding to the electrophoretic pattern $B_{2}$ (see Results and Table 1), whereas six exhibited esterase mobilities corresponding to the electrophoretic pattern $B_{1}$ (Goullet \& Picard, 1986b). Fourteen strains corresponding to pattern $\mathrm{B}_{2}$ were clearly distinguished by MCA (Fig. 1). As previously observed, the strains with this latter pattern possessed $\alpha$-haemolysin and MRHA more frequently than did all the strains with pattern $B_{1}$. Analysis of esterases corroborated the distinction of the 22 strains of group III which resulted from the analysis of 35 enzymes. Among the 16 strains having pattern $B_{2}, 14$ constitute group $B 2$, and two (strains 66 and 67) are in group $B 1$. Five of the six strains of pattern $B_{1}$ belonged to group $C$. The fact that no structural relationship could be drawn in terms of amino acid substitution between variants of pattern $B_{1}$ and variants of pattern $B_{2}$ (Picard et al., 1987) and that group B2 was exclusively composed of strains having pattern $B_{2}$ indicate that these strains, which are frequently implicated in extraintestinal infections (Goullet \& Picard, 1986b), correspond to a taxonomically distinct cluster within E. coli.

We thank Professor R. K. Selander from the University of Rochester for the ECOR strains, Professor M. Tenenhaus from École des Hautes Études Commerciales and Monsieur J.-P. Gauchi from Rhones Poulenc Recherches - Centre d'Aubervilliers, for mathematical advice and computer analyses, and Madame C. Gaillard for technical assistance.

This work was supported by grants from the Conseil Scientifique de la Faculté Xavier Bichat (Université Paris VII). 


\section{REFERENCES}

Goullet, PH. (1973). An esterase zymogram of Escherichia coli. Journal of General Microbiology 77, 27-35.

GoULLET, PH. (1980). Esterase electrophoretic pattern relatedness between Shigella species and Escherichia coli. Journal of General Microbiology 117, 493-500.

Goullet, Ph. \& PiCARD, B. (1985). A two-dimensional electrophoretic profile for bacterial esterases. Electrophoresis 6, 132-135.

Goullet, PH. \& Picard, B. (1986a). Comparative esterase electrophoretic polymorphism of Escherichia coli isolates obtained from animal and human sources. Journal of General Microbiology 132, 18431851.

Goullet, Ph. \& PiCard, B. (1986b). Highly pathogenic strains of Escherichia coli revealed by distinct electrophoretic pattern of carboxylesterase B. Journal of General Microbiology 132, 1853-1858.

Goullet, PH. \& PICARD, B. (1987). Differentiation of Shigella by esterase electrophoretic polymorphism. Journal of General Microbiology 133, 1005-1017.

GreenaCre, M. J. (1984). Theory and Applications of Correspondences. London: Academic Press.

Lebart, L., MorineaU, A. \& WarWICK, K. M. (1984). Multivariate Descriptive Analysis: Correspondence Analysis and Related Techniques for Large Matrices. New York: Wiley-Interscience.

NEI, M. (1978). Estimation of average heterozygosity and genetic distance from a small sample of individuals. Genetics 89, 583-590.

Ochman, H. \& Selander, R. K. (1984). Standard reference strains of Escherichia coli from natural populations. Journal of Bacteriology 157, 690-693.

Ochman, H., Whittam, T. S., Caugant, D. A. \& SelANDER, R. K. (1983). Enzyme polymorphism and genetic population structure in Escherichia coli and Shigella. Journal of General Microbiology 129, 27152726.

Pardee, A. B., Jacob, F. \& Monod, J. (1959). The genetic control and cytoplasmic expression of 'inducibility' in the synthesis of $\beta$-galactosidase by $E$. coli. Journal of Molecular Biology 1, 165-176.

Picard, B., Goullet, PH. \& Krishnamoorthy, R. (1987). A novel approach to study the structural basis of enzyme polymorphism: analysis of carboxylesterase B of Escherichia coli as a model. Biochemical Journal 241, 877-881.

Selander, R. K., Caugant, D. A., Ochman, H., Musser, J. M., Gilmour, M. N. \& WhittaM, T. S. (1986). Methods of multilocus enzyme electrophoresis for bacterial population genetics and systematics. Applied and Environmental Microbiology 51, 873-884.

Selander, R. K., Caugant, D. A. \& Whittam, T. S. (1987). Genetic structure and variation in natural populations of Escherichia coli. In Escherichia coli and Salmonella typhimurium, Cellular and Molecular Biology, vol. 2, pp. 1625-1648. Edited by J. L. Ingraham and others. Washington, DC: American Society for Microbiology.

Tenenhaus, M. \& Young F. W. (1985). An analysis and synthesis of multiple correspondence analysis, optimal scaling, dual scaling, homogeneity analysis and other methods for quantifying categorical multivariate data. Psychometrika 50, 91-119.

Whittam, T. S., Ochman, H. \& Selander, R. K. (1983). Multilocus genetic structure in natural populations of Escherichia coli. Proceedings of the National Academy of Sciences of the United States of America 80, 1751-1755. 